\title{
The life cycle impact for platinum group metals and lithium to 2070 via surplus cost potential
}

\author{
Dominik Jasiński $^{1}$ • James Meredith ${ }^{2}$ - Kerry Kirwan ${ }^{1}$ \\ Received: 27 September 2016 / Accepted: 23 April 2017 / Published online: 11 May 2017 \\ (C) The Author(s) 2017. This article is an open access publication
}

\begin{abstract}
Purpose A surplus cost potential (SCP) indicator has been developed as a measure of resource scarcity in the life cycle impact assessment (LCIA) context. To date, quality SCP estimates for other minerals than fossils are either not yet available or suffer methodological and data limitations. This paper overcomes these limitations and demonstrate how SCP estimates for metals can be calculated without the utilisation of ore grade function and by collecting primary economic and geological data.

Methods Data were collected in line with the geographical distribution, mine type, deposit type and production volumes and total production costs in order to construct costcumulative availability curves for platinum group metals (PGMs) and lithium. These curves capture the total amount of known mineral resources that can be recovered profitably at various prices from different types of mineral deposits under current conditions (this is, current technology, prevailing labour and other input prices). They served as a basis for modelling the marginal cost increase, a necessary parameter for estimating the SCP indicator. Surplus costs were calculated for different scenario projections for future mineral production
\end{abstract}

Responsible editor: Andrea J. Russell-Vaccari

Electronic supplementary material The online version of this article (doi:10.1007/s11367-017-1329-4) contains supplementary material, which is available to authorized users.

Dominik Jasiński

d.jasinski@warwick.ac.uk

1 Warwick Manufacturing Group, University of Warwick, Coventry CV4 7AL, UK

2 Department of Mechanical Engineering, University of Sheffield, Sheffield S1 3JD, UK considering future market dynamics, recyclability rates, demand-side technological developments and economic growth and by applying declining social discount rate. Results and discussion Surplus costs were calculated for three mineral production scenarios, ranging from $\left(\mathrm{US} \$_{2014} / \mathrm{kg}\right.$ ) 6545-8354 for platinum, 3583-4573 for palladium, 828110,569 for rhodium, 513-655 for ruthenium, 3201-4086 for iridium and 1.70-5.80 for lithium. Compared with the current production costs, the results indicate that problematic price increases of lithium are unlikely if the latest technological trends in the automotive sector will continue up to 2070 . Surplus costs for PGMs are approximately one-third of the current production costs in all scenarios; hence, a threat of their price increases by 2070 will largely depend on the discovery of new deposits and the ability of new technologies to push these costs down over time. This also applies to lithium if the increasing electrification of road transport will continue up to 2070 .

Conclusions This study provides useful insight into the availability of PGMs and lithium up to 2070. It proves that if time and resources permit, reliable surplus cost estimates can be calculated, at least in the short-run, based on the construction of one's own curves with the level of quality comparable to expert-driven consulting services. Modelling and incorporating unknown deposits and potential future mineral production costs into these curves is the subject of future work.

Keywords Life cycle impact assessment $\cdot$ Marginal cost increase $\cdot$ Metal scarcity $\cdot$ Minerals cost-cumulative availability curves $\cdot$ Resource depletion $\cdot$ Surplus cost
Abbreviations
ADP Abiotic resource depletion potential
EV Electric vehicle 


$\begin{array}{ll}\text { FCV } & \text { Fuel cell vehicle } \\ \text { HDV } & \text { Heavy-duty vehicle } \\ \text { HV } & \text { Hybrid vehicle } \\ \text { IEA } & \text { International Energy Agency } \\ \text { LCA } & \text { Life cycle assessment } \\ \text { LCIA } & \text { Life cycle impact assessment } \\ \text { LDV } & \text { Light-duty vehicle } \\ \text { MCI } & \text { Marginal cost increase } \\ \text { MDV } & \text { Medium-duty vehicle } \\ \text { PHEV } & \text { Plug-in hybrid electric vehicle }\end{array}$

\section{Introduction}

Over the last two decades, several models for evaluating resource availability and assessing the potential of resource depletion have been proposed in the context of life cycle impact assessment (LCIA). These models can be classified into four major groups: (1) models aggregating resource consumption based on mass or energy (Huijbregts et al. 2010; Saurat and Ritthoff 2013), (2) models quantifying thermodynamic losses (e.g. exergy and solar energy) (Finnveden and Östlund 1997; Dewulf et al. 2007), (3) models measuring diminishing geological stock available within planetary boundaries (Guinée 1995; Hauschild and Wenzel 1998; Van Oers et al. 2002); and, (4) opportunity cost models measuring the sacrifice that society has to make in order to obtain an additional quantity of a given resource (Humphreys 2013; Drielsma et al. 2016), such as higher energy requirements (Müller-Wenk 1998; Goedkoop and Spriensma 2001; Jolliet et al. 2003) and the change in future marginal extraction costs resulting from the combination of depletion, exploration results and costreducing innovation (Steen 1999; Goedkoop et al. 2008; Ponsioen et al. 2014).

The first two groups of models are considered inadequate indicators of resource depletion because they address the consumption of natural resources as opposed to resource scarcity and declining availability (Lindeijer et al. 2002; Stewart and Weidema 2005; Rørbech et al. 2014). Although the third group of methods gives an indication of time frames as well as the rates at which minerals are depleted in line with presentday technology and demand, Tilton (2003) proved that the life expectancy of most minerals in the Earth's crust will exceed millions, or even billions, of years. This suggests that the physical availability of minerals will never become a serious issue for mankind. Rather, it is more likely that the rising costs of extracting a mineral such as copper $(\mathrm{Cu})$ from the Earth will eradicate demand for it a long time prior to exhaustion of the physical resource itself (Tilton and Lagos 2007; Humphreys, 2013). For this reason, a function of the long-run costs and prices of minerals provides a more promising early warning indicator of impending resource scarcity than do measures related to their physical availability (Yaksic and Tilton 2009; Humphreys 2013; Drielsma et al. 2016).

A surplus cost potential indicator, classified under the umbrella of opportunity cost methods, measures the net present value of the increase in mineral production costs associated with each additional extraction of a mineral commodity (Goedkoop et al. 2008; Ponsioen et al. 2014). A basic assumption of the method is that mining companies operate mainly to maximise profits and therefore higher quality and the least expensive deposits are mined first. This, however, is not always the case mainly because of the discovery of new deposits, cost-reducing technological innovations and other geopolitical factors such as trade barriers or strategic stocking of resources (Tilton 2003; Ponsioen et al. 2014; Drielsma et al. 2016). Nonetheless, the uniqueness and strength of this method lies in its ability to model resources that are produced as coproducts by using a system of price allocation. Many minerals are almost exclusively mined as co-products of other metals (e.g. rhodium, ruthenium, iridium and rare earth elements), and surplus cost does more justice to the real world than methods that only address the depletion of single minerals (EC-JRC 2011; Hauschild et al. 2013). Surplus cost was selected by the EC-JRC (EC-JRC 2011) as showing promise and as the best of the existing measures available for capturing resource depletion at the endpoint level, although it is not yet considered sufficiently mature for recommendation.

To date, quality surplus cost estimates have been derived only for fossil fuels (oil, natural gas and coal) (see Ponsioen et al. 2014). These estimates were based on the actual data of mineral reserves and production costs published by relevant institutions, such as the International Energy Agency (IEA) and German Federal Institute for Geosciences and Natural Resources. Surplus cost estimates for other minerals are either not yet available or require the improvements. For example, the utilisation and linking of the ore grade decrease function with the increasing marginal extraction cost of metals in existing surplus cost studies has been heavily criticised by relevant organisations in the metals and minerals mining sector (e.g. the European Association of Mining Industries, the Nickel Institute and the European Copper Institute) (see Drielsma et al. 2016). Factors other than ore grades affect the cost of mineral extraction (e.g. mine type, new discoveries, labour cost and technological developments). Hence, minerals other than fossils (e.g. metals) could be modelled without an ore grade decrease function, something that in any case has been heavily criticised by authoritative bodies. Furthermore, production cost data pertaining to minerals other than fossils are much more difficult to obtain than, for example, geological data (Yaksic and Tilton 2009). Existing surplus cost studies for metals used a simplified approach by assuming constant mining costs across all mines (see Goedkoop et al. 2008). Vieira et al. (2016) adjusted surplus cost estimates for 12 metals by using the actual cost data purchased from the commercial 
database World Mine Cost Data Exchange. However, these data do not recognise the characteristics of different deposits and mining technologies. Also, these data are not publically available and it is therefore not possible to reproduce and validate existing surplus cost estimates.

The goal of this paper is to overcome these limitations and demonstrate how surplus cost estimates for metals, similarly to fossils, could be calculated without the utilisation of ore grade function and without the need to rely on authoritative institutions or purchase data from commercial databases. The metals selected in this study are platinum, palladium, rhodium, ruthenium and iridium, all of which are platinum group metals (PGMs). The results for PGMs will be compared with those for lithium, which is a potential substitute for PGMs in future automotive applications, depending on the rate and extent to which electric cars replace cars with internal combustion engines.

\section{Research methods}

\subsection{The surplus cost potential indicator}

The surplus cost potential indicator $\left(\mathrm{SC}_{x}\right)$ is based on three parameters (Ponsioen et al. 2014), as evident in Eq. (1) and Eq. (2):

$\mathrm{SC}_{x}=\sum_{t=1}^{T}\left(\operatorname{MCI}_{x}{ }^{*} P_{x, t}{ }^{*} \frac{1}{(1+d)^{t}}\right)$

where,

$\mathrm{MCI}_{x}=\frac{\Delta \text { Cost }_{x}}{\Delta P_{x}}$

$\mathrm{MCI}_{x}$ is the marginal cost increase of mineral $x$ expressed as a ratio of the change in the cost per kilogramme of mineral $x$ $\left(\Delta \operatorname{Cost}_{x}\right)$ to the change in the amount to be produced in the future $\left(\Delta P_{x}\right) . P_{x, t}$ is the annual production of mineral $x$ in year $t$ counting from the base year, $T$ is the year in which the considered mineral resource $x$ is depleted and $d$ is the discount rate. The process of modelling and estimating these parameters is explained in the following subsections.

\subsection{The construction of cost-cumulative availability curves}

The MCI parameter can be derived from the function of cumulative mineral production and difference in its production costs (Ponsioen et al. 2014). This requires the construction of cost-cumulative availability curves which provide geological knowledge of existing mineral deposits, their sizes as well as potential costs at which these deposits could be extracted. Data for constructing these curves is available for lithium (see Yaksic and Tilton,
2009), but not for PGMs. The development process of the cost-cumulative availability curve for PGMs is summarised in Fig. 1, and is explained as follow:

- Phase 1: involved collecting and analysing data about the distribution of known PGM deposits, mining companies and projects around the globe as well as data on deposit types, mine types, ore grades, total resources, production volumes, operational and capital costs for PGM mines and deposits. The best data for phase 1 were collected from the US Geological Survey (USGS 2014), British Geological Survey (BGS 2009), Geoscience Australia (Hoatson et al. 2014), Natural Resources Canada (NRC 2015), Geological Survey of Finland (online), Johnson Matthey (2013b), Department of Mineral Resources in the Republic of South Africa (Moumakwa 2014), International Platinum Group Association and a number of annual, technical and production reports, press releases, investor presentations, feasibility studies and official websites of PGM mining, exploration and consulting companies.

- Phase 2: involved estimating a geological composition of PGMs depending on the deposit types. A typical deposit contains various metals but there is usually a main metal that justifies the exploitation of a given deposit (Vieira et al. 2016). PGMs are mined as both the main and accompanying metals of nickel (Ni) and copper deposits (Hagelüken and Meskers 2010). A general concentration of PGM elements was assumed based on the existing literature (Theart and De Nooy 2001; Crundwell et al. 2011; Zientek et al. 2014) and the websites and reports of mining and exploration companies such as Stillwater Mining Company, Platina Resources Limited and North America Palladium.

- Phase 3: annual operating costs (also called cash costs), capital expenditures and production volumes were collected from a variety of sources (see the data collection section, phase 1). The estimation of capital expenditures on an annual basis is more complicated than for operational costs since capital expenditures are incurred largely at the start of mining, with additional irregular expenditures incurred in subsequent years of running the project. If ultimate capital expenditures for the lifetime of the project are not known, the annual distribution of capital costs is best reflected by the depreciation of buildings and equipment (Aguilera et al. 2009). This approach was also adopted in this study. An accounting technique of joint and byproduct costing based on sale values had to be applied in order to allocate total production costs to specific mining outputs (Drury 2013). All costs were adjusted for inflation using the CPI inflation calculator available at the Bureau of Labor Statistics website and converted into US dollars for the year $2014\left(\$ U_{2014}\right)$. 

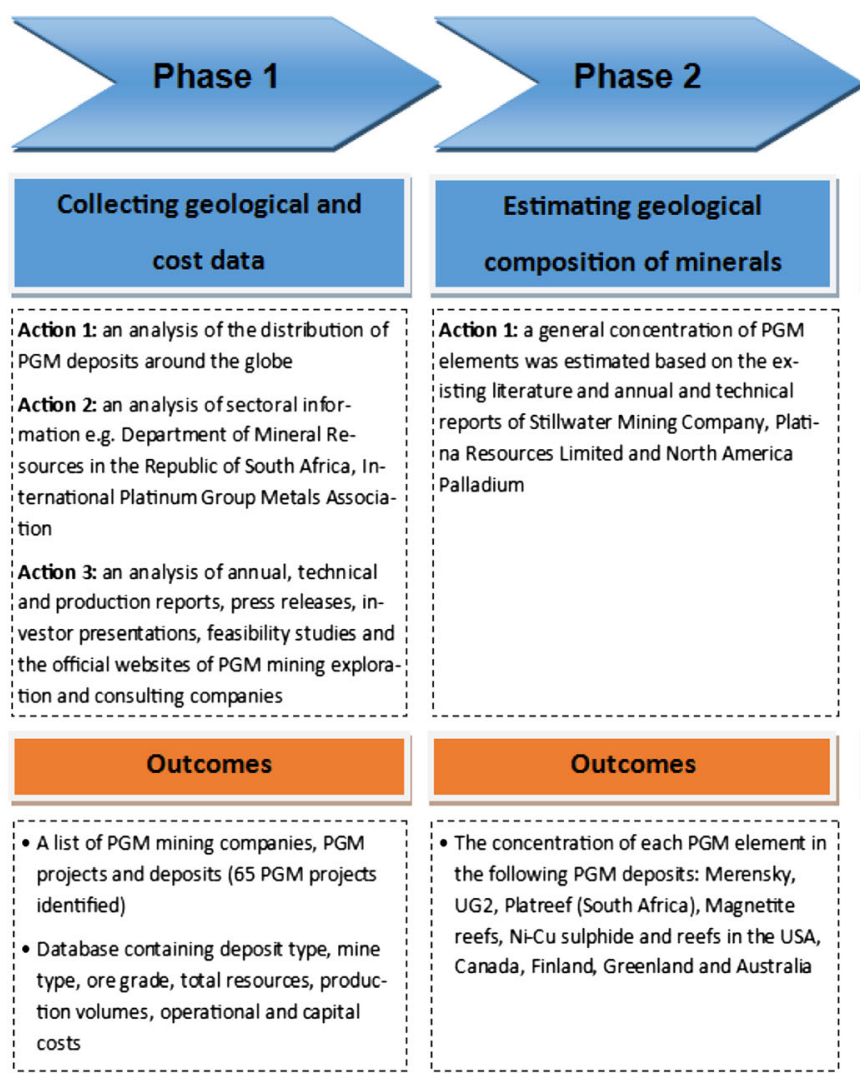

Action 1: a general concentration of PGM elements was estimated based on the existing literature and annual and technical reports of Stillwater Mining Company, Platina Resources Limited and North America Palladium
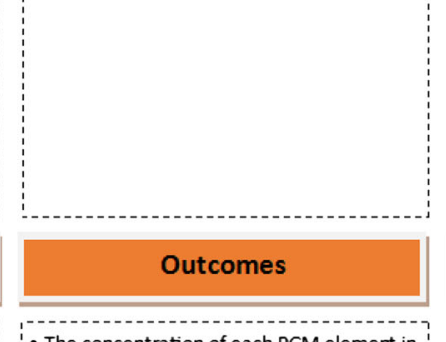

- The concentration of each PGM element in the following PGM deposits: Merensky, UG2, Platreef (South Africa), Magnetite reefs, $\mathrm{Ni}-\mathrm{Cu}$ sulphide and reefs in the USA, Canada, Finland, Greenland and Australia

Fig. 1 The process of constructing cost-cumulative curves for PGMs

- Phase 4: following the estimation of geological distribution and production costs, the cost-cumulative availability curve for PGM deposits and countries was then constructed following a process similar to that used by Yaksic and Tilton (2009) for lithium. For each deposit, a minimum and maximum production cost was selected based on the calculated total costs per unit produced. This selection of minima and maxima enabled the dynamics and uncertainties associated with the potential fluctuation of PGM production costs in the future to be captured. It also allowed for the inclusion in the curve of those known projects (deposits) for which production costs could not be calculated, assuming they had the potential to be mined within the cost range estimated for other deposits in the country that had similar geological configurations, geographical locations and socio-economic situations. The cost-cumulative availability curve was created by ordering PGM deposits based on their minimum production costs, from lowest to highest, and adding together the amount of PGMs available within each deposit.

Each phase of constructing the cost-cumulative availability curve for PGMs as well as underlying data is explained in details in supplementary information. A similar

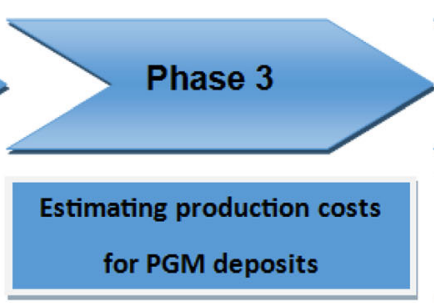

Action 1: annual operating costs (also called cash costs) and capital expenditures collected in Phase 1 were added together to estimate the total cost per year

Action 2: joint and by-product costing method based on sales values was applied in order to allocate total production costs to specific mining outputs

Action 3: the total cost per mineral was divided by the output of a given mineral to estimate the total annual cost per unit produced

Outcomes
The total cost per year for the last 5 years
reported
The total cost per unit produced for each
mineral converted into US dollars for the
year 2014 (US\$ $\$_{2014}$ ) (cost calculated for 43
PGM mines and projects)

Phase 4

Constructing cost-cumulative availability curves

Action 1: a min imum and maximum production cost for each PGM deposit was selected based on the calculated total costs per unit produced

Action 2: PGM deposits were ordered based on their minimum production costs, from lowest to highest

Action 3: the amount of PGMs available within each deposit was added together

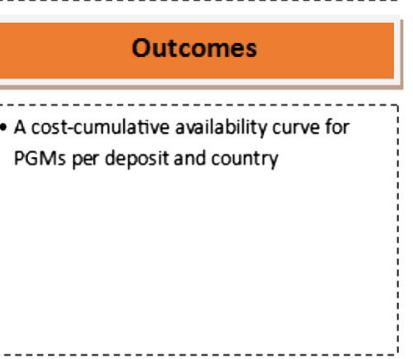

curve per deposit type and country was constructed for lithium based on data published by Yaksic and Tilton (2009).

\subsection{Modelling the MCI parameter}

In order to develop a cumulative production slope representing the $\mathrm{MCI}$ parameter from the minimum and maximum costs per deposit type of PGMs and lithium, Ponsioen et al. (2014) proposed a statistical Monte Carlo technique, a simulation method that relies on repeated, multiple and random trials and statistical analysis in order to determine the expected value from a probable distribution of values (Barreto and Howland 2005; Raychaudhuri 2008; Korn et al. 2010). Assuming that the mineral production cost per deposit is a random number between the minima and maxima, the Monte Carlo method enables generation of the expected value with a specified level of certainty. There are a number of different software packages for use with the Monte Carlo method; however, Monte Carlo simulations can also be performed using Microsoft Excel spreadsheets (Barreto and Howland 2005; Raychaudhuri 2008), as was the case in this study. The process employed in running Monte Carlo simulations was as follows: 
- The total known resources (assumed to be equal to proved and probable reserves and measured, indicated and inferred mineral resources) available for each mineral were divided into equal production intervals for each mineral, respectively $10,000 \mathrm{~kg}$ for platinum, $10,000 \mathrm{~kg}$ for palladium, $5000 \mathrm{~kg}$ for ruthenium, $1200 \mathrm{~kg}$ for rhodium, $1000 \mathrm{~kg}$ for iridium and $2 \mathrm{E}+10 \mathrm{~kg}$ for lithium from oceans and $2 \mathrm{E}+7 \mathrm{~kg}$ for other lithium deposits.

- A range of production costs was allocated to each interval based on the cumulative availability and production cost per deposit.

- Assuming a uniform distribution of production costs between the minima and maxima, random values for each production interval were generated using the $R A N D($ ) function in Excel.

- In order to obtain an accurate value, the Monte Carlo method is based on a large number of simulations. The higher the number of simulations, the more accurate the results that can be obtained; however, the number of simulations is not that critical provided confidence bounds are also computed (Korn et al. 2010). Similar to the process used by Ponsioen et al. (2014), 10,000 simulations were run for each production interval, the minimum for industry standards (Field 2009).

Cost values obtained from the Monte Carlo simulations were ordered from the lowest to highest and the costcumulative production curve was developed with the range for each production interval and the mean slope representing the MCI of each mineral. Further statistical analysis was conducted, including estimation of the median, standard deviation and confidence bounds in order to estimate the precision of the obtained values (Raychaudhuri, 2008).

\subsection{Future mineral production}

One of the challenges in estimating the surplus cost indicator is predicting how the production of a given mineral will change over time. Scenario analysis is a critical tool in the world of finance and economics and is used to determine and analyse events that may take place in the future (Ringland and Schwartz 1998; Van der Heijden 2011).

Three different scenarios for the future production of PGMs and lithium were developed. Common conditions for all three scenarios, such as future population and economic growth, demand for minerals from non-automotive uses and recyclability and mineral loadings per vehicle, are summarised in Table 1.

A major factor set to influence demand for PGMs and lithium over the coming decades is the use of whichever energy source becomes dominant for road transport. For example, the automotive sector's use of PGMs should decline and demand for lithium increase if, or once, electric cars replace cars with internal combustion engines. On the other hand, current automotive fuel cells rely heavily on platinum-coated catalytic converters, meaning any penetration of fuel cell technology will have a severe impact on demand for PGMs, with one fuel cell vehicle (FCV) requiring approximately $30 \mathrm{~g}$ of platinum (Sun et al. 2011). The projected demand for lightduty vehicles (LDVs), medium-duty vehicles (MDVs) and heavy-duty vehicles (HDVs) in three different energy technology penetration scenarios was based on two IEA reports; Energy Technology Perspectives (Taylor 2010) and Technology Roadmap: Electric and Plug-in Hybrid Electric Vehicles (Tanaka 2011). These projections are presented in Fig. 2e and are explained as follows:

- Scenario 1 (baseline): in the baseline scenario, existing trends will continue and petrol and diesel vehicles will be dominant in the future with only a small proportion of hybrid vehicles (HVs) for LDVs and natural gas biofuels for MDVs and HGVs.

- Scenario 2 (Blue map): the Blue map scenario assumes a $50 \%$ global reduction in greenhouse gas (GHG) emissions by 2050 relative to their 2000 level as the result of a strong mix of policy instruments focusing on climate change. Obtaining the maximum efficiency gains in reducing GHG emissions will require a large penetration of plugin hybrid electric vehicles (PHEVs), fully electric vehicles (EVs) and FCVs for LDVs. Electrification and fuel cells are also assumed for MDVs, along with an increase in the use of alternative fuels in HDVs, in particular advanced biofuels, gas-to-liquid, coal-to-liquid and natural gas.

- Scenario 3 (Blue map without FCVS): the third scenario is based on the same assumptions as scenario 2, with the difference that the automotive sector will shift towards full electrification without penetration of fuel cell technology. Hydrogen fuel cell systems have the potential to be a clean and efficient power option for vehicles, but also have many technical and economic challenges still to overcome prior to their full commercialisation (Sun et al. 2011).

\subsection{Selecting a discount rate}

The selection of an appropriate discount rate is based on value choices and is therefore subjective. Environmental economists are far from a consensus on which discount rate to apply (Kahn and Greene 2013). For example, Ponsioen et al. (2014) used three discount rates $(0,3$ and $15 \%)$ to estimate surplus cost for fossils. The ReCiPe method used a 2-5\% range of discount rates (Goedkoop et al. 2008). The World Bank utilised a $4 \%$ discount rate to estimate the snatural capital in their wealth accounts (Jarvis et al. 2011). The UN System of EnvironmentalEconomic Accounts (2012) recognises two types of discount 
Table 1 PGM and lithium demand forecast assumptions to 2070

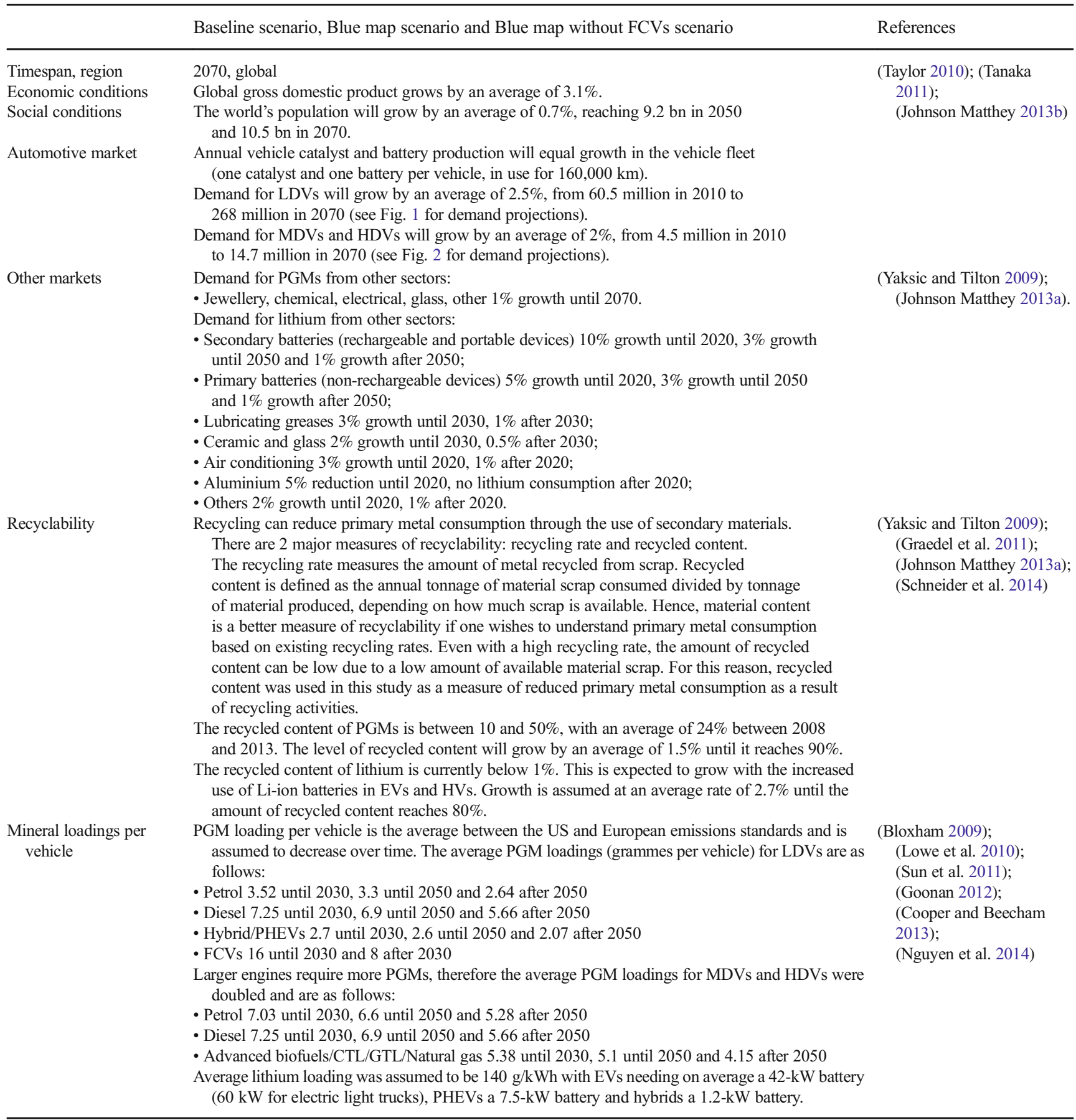

rate: individual and social. Individual discount rates consider the preferences and perspectives of an individual consumer or company and the likelihood of them earning interest. Social discount rates consider time and risk for society as a whole, and societies, unlike individuals, must give greater consideration to the interests of future generations. For this reason, social discount rates are usually lower than individual discount rates. Private companies tend to use discount rates higher than $10 \%$, while social discount rates are usually below 5\% (Ponsioen et al. 2014).
The UK Office for National Statistics recommends a third option of choosing a uniform $3.5 \%$ social discount rate, to be used for all types of natural assets regardless of the purpose of the exercise (Kahn and Greene 2013). This option was first outlined in HM Treasury's Green Book for use by UK authorities following consultation between experts and government officials. It has since been adopted by the French authorities and is also considered by US officials for all sustainability projects (Cropper et al. 2014). This option uses a declining 

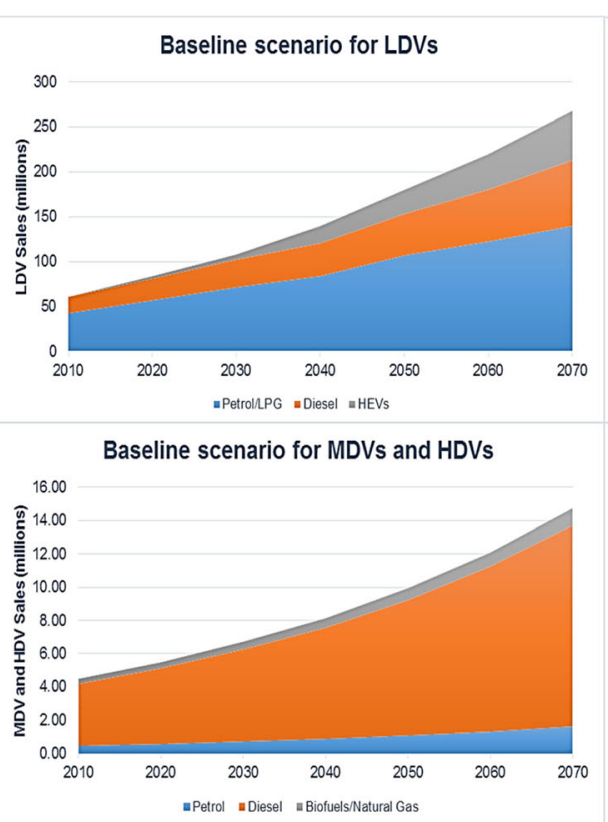
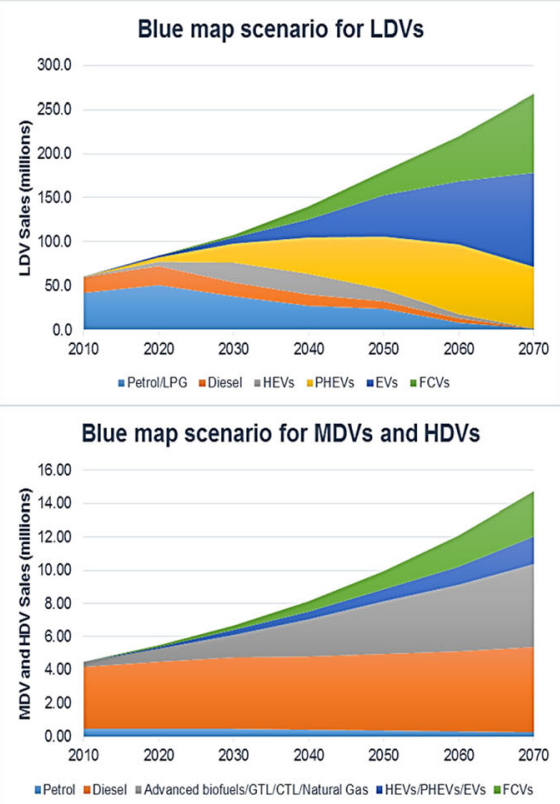

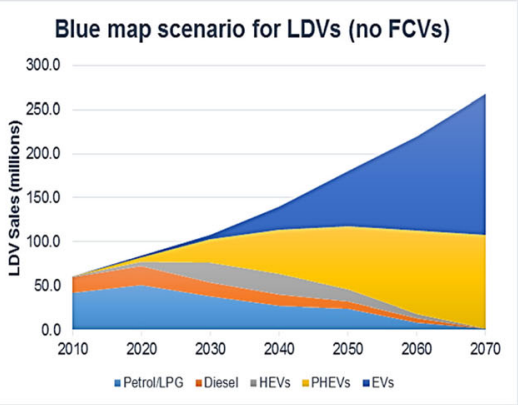

Blue map scenario for MDVs and HDVs (no FCVs)

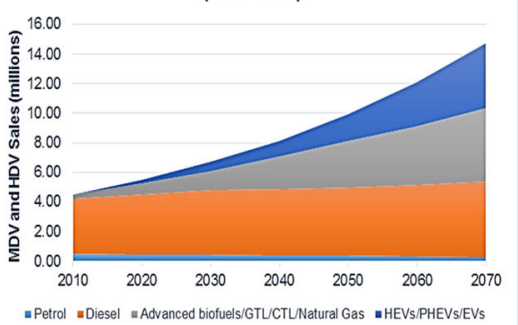

Fig. 2 Projections of future demand for vehicles in three different scenarios (adapted from Taylor, 2010 and Tanaka, 2011)

uniform discount rate for impacts assessed over the very long term, at the rates presented in Table 2.

Declining long-term discount rates better represent the distribution of uncertain levels of economic growth into the distant future, or times when growth is unevenly distributed over time. Since natural resources are of long-term value to society, it makes sense to use the declining social discount rate for the purpose of this study.

\section{Results}

\subsection{Cost-cumulative availability of PGMs and lithium}

PGMs occur in a wide variety of geological settings and are derived from deposits of several types, with two major deposit groups being: platinum group element (PGE)-dominant deposits (Merensky, UG2, Platreef and the dunite pipes) and Ni-Cu-dominant deposits (see BGS 2009). In PGE-dominant deposits, PGMs are the dominant economic components, with $\mathrm{Ni}$ and $\mathrm{Cu}$ as minor by-products. $\mathrm{Ni}-\mathrm{Cu}$-dominant deposits are the most important sources of nickel worldwide. Copper, cobalt (Co), PGEs (primarily palladium), gold and sometimes silver $(\mathrm{Ag})$ and chromium $(\mathrm{Cr})$ are mined as accompanying

Table 2 Declining social discount rate proposed by HM Treasury (2003)

\begin{tabular}{lllllll}
\hline Number of years & $0-30$ & $31-75$ & $76-125$ & $126-200$ & $201-300$ & $300+$ \\
\hline Discount rate & $3.5 \%$ & $3 \%$ & $2.5 \%$ & $2 \%$ & $1.5 \%$ & $1 \%$ \\
\hline
\end{tabular}

metals (BGS 2009). Of the 65 PGM projects examined, the total cost per unit produced was estimated for 43 . Based on these estimates, a minimum and maximum cost was allocated to each deposit and the cost-cumulative availability curve for PGMs was constructed as shown in Fig. 3. The underlying data used for construction of the CAC, including a list of known PGM deposits, along with estimates of their quantities and production costs, are provided in Table S3 and S4 in the Electronic Supplementary Material.

Accompanying metals usually contribute very little to the total revenue of a mining company and therefore the production cost of PGMs from Ni-Cu-dominant deposits (mostly in Russia, China and Canada) is lower than in the case of PGEdominant deposits. Also, the production cost of PGMs from $\mathrm{Ni}-\mathrm{Cu}$-dominant deposits depends largely on the production costs and market values of $\mathrm{Ni}$ and $\mathrm{Cu}$ rather than the PGMs themselves. For example, an increase in the production costs and a decrease in the prices of $\mathrm{Ni}$ and $\mathrm{Cu}$ will shift the segment of the $\mathrm{CAC}$ pertaining to $\mathrm{Ni}-\mathrm{Cu}$-dominant deposits up despite there being no change or disruption to the PGM market. However, deposits where PGMs are only a by-product still make a significant contribution to the total availability of PGMs and were therefore included in Fig. 3.

To date, lithium has primarily been extracted, in all parts of the world, from two types of resources-brines and minerals (spodumene, lepidolite, petalite, amblygonite and eucriptite). Brines are currently the least expensive (no mining is required) and most relevant source of lithium. In addition to brines and mineral deposits, lithium can also be obtained from clays (hectorite) and seawater, both of which are potential future sources. The major global producers are Chile, 


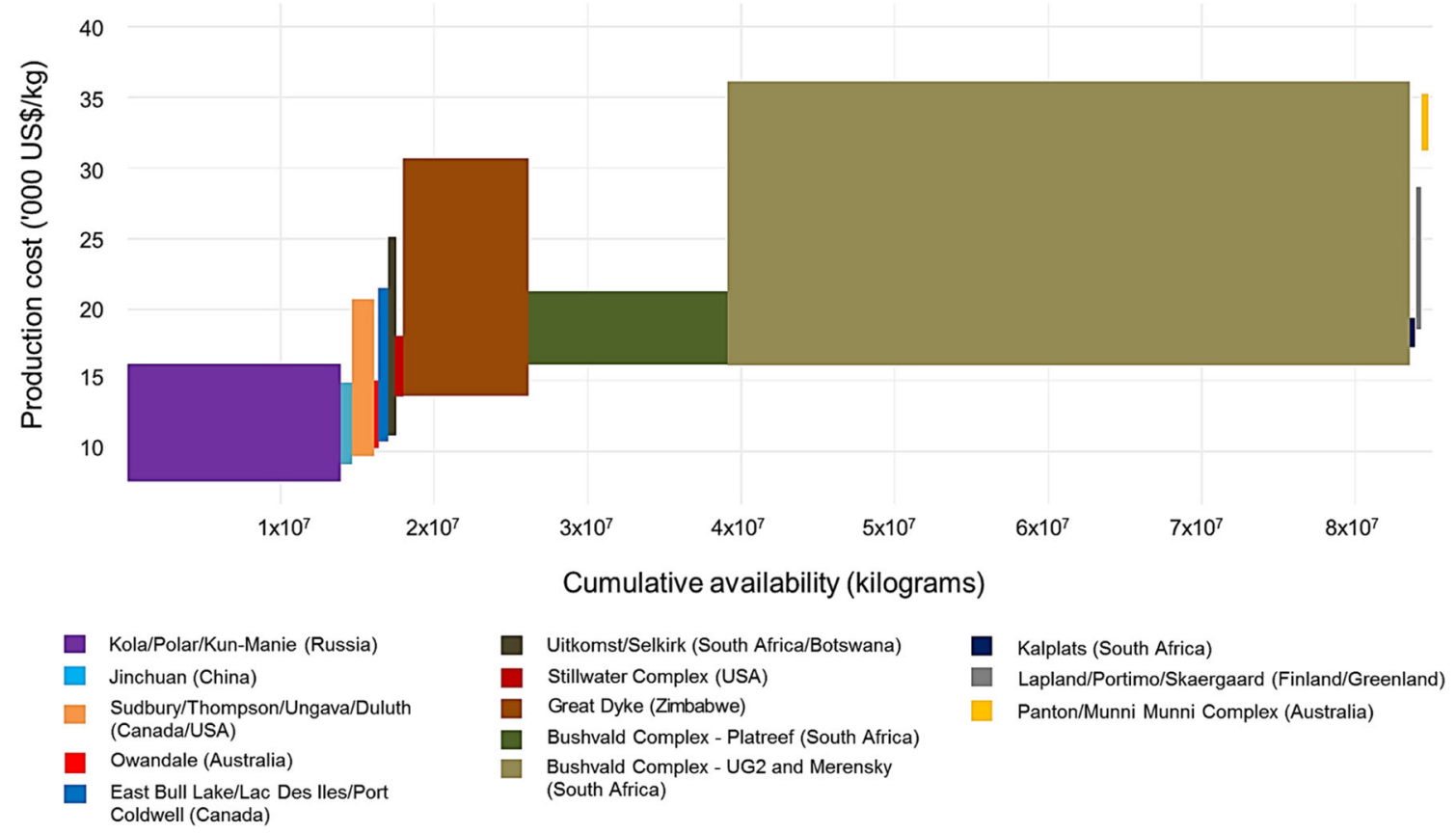

Fig. 3 Cost-cumulative availability of PGMs per deposit

Australia, Argentina, China and the USA, accounting for over $90 \%$ of the total production (Yaksic and Tilton 2009). Lithium, the same as PGMs, is mined both as a dominant metal (mainly from Li-rich pegmatites, which also contain other metals such as tin and beryllium) and as a by-product of other elements, mainly potash (K) (Nassar et al. 2015).

The cost-cumulative availability of lithium is presented in Fig. 4 and the underlying data used to construct the curve are given in Table S5 in the Electronic Supplementary Material. The original production cost data (vertical axis) in Yaksic and Tilton (2009) were given in dollars per pound of lithium carbonate and available resources were measured in tonnes of contained lithium. In order to eliminate this difference in units, production cost data were converted into dollars per kilogramme of contained lithium by assuming that $5.323 \mathrm{~kg}$ of lithium carbonate contains $1 \mathrm{~kg}$ of lithium metal. Production costs were then adjusted for inflation to convert data from 2009 to 2014. The horizontal axis shows available resources after processing losses and assumes recovery rates of $50 \%$ for minerals, $50 \%$ for hectorites, $45 \%$ rate for brines and $20 \%$ for oceans.

Figure 4 is incomplete as it contains only a small proportion of the lithium available from seawater (oceans). This is because the amount of lithium recoverable from the oceans is vast, 44.8 billion tonnes, and it was not possible to fit this into the graph with the lithium deposits. This does not pose a serious problem provided we keep in mind there is an almost infinite supply of lithium from seawater (see Table S5 in the Electronic
Supplementary Material for the specific amounts of lithium recoverable from each deposit).

\subsection{MCI results for PGMs and lithium}

A statistical overview of the Monte Carlo simulations and MCI results obtained for each PGM and for lithium are presented in Table 3. The results represent the average MCI per mineral with 95\% confidence bounds. The average difference between the mean and median for all metals is $0.45 \%$, suggesting the data are normally distributed (Levin and Rubin 1998). Individual cost-cumulative production curves for each metal, with the mean slope and cost range per $10,000 \mathrm{~kg}$ of platinum, $10,000 \mathrm{~kg}$ of palladium, $5000 \mathrm{~kg}$ of ruthenium, $1200 \mathrm{~kg}$ of rhodium, $1000 \mathrm{~kg}$ of iridium and $2 \times 10^{10} \mathrm{~kg}$ of lithium from oceans and $2 \times 10^{7} \mathrm{~kg}$ from other deposits, are given in Fig. 5. The slope for lithium is incomplete for the same reasons as in the case of the cost-cumulative availability graph. The cumulative production of each individual PGM was estimated based on the general concentration of PGM elements in different deposit types (see Table S1 in Electronic Supplementary Material). Production of ruthenium and iridium is only reported by companies operating at the Bushvald Complex in South Africa. Companies mining other deposits, including all $\mathrm{Ni}$-Cu-dominant deposits, report production of only two or three major PGMs, including platinum, palladium and rhodium.

It is evident from Table 3 that the MCI estimates for the six metals are different, ranging from $2.292 \times 10^{-2}$ for iridium to $1.116 \times 10^{-9}$ for lithium. The reasons for this substantial 


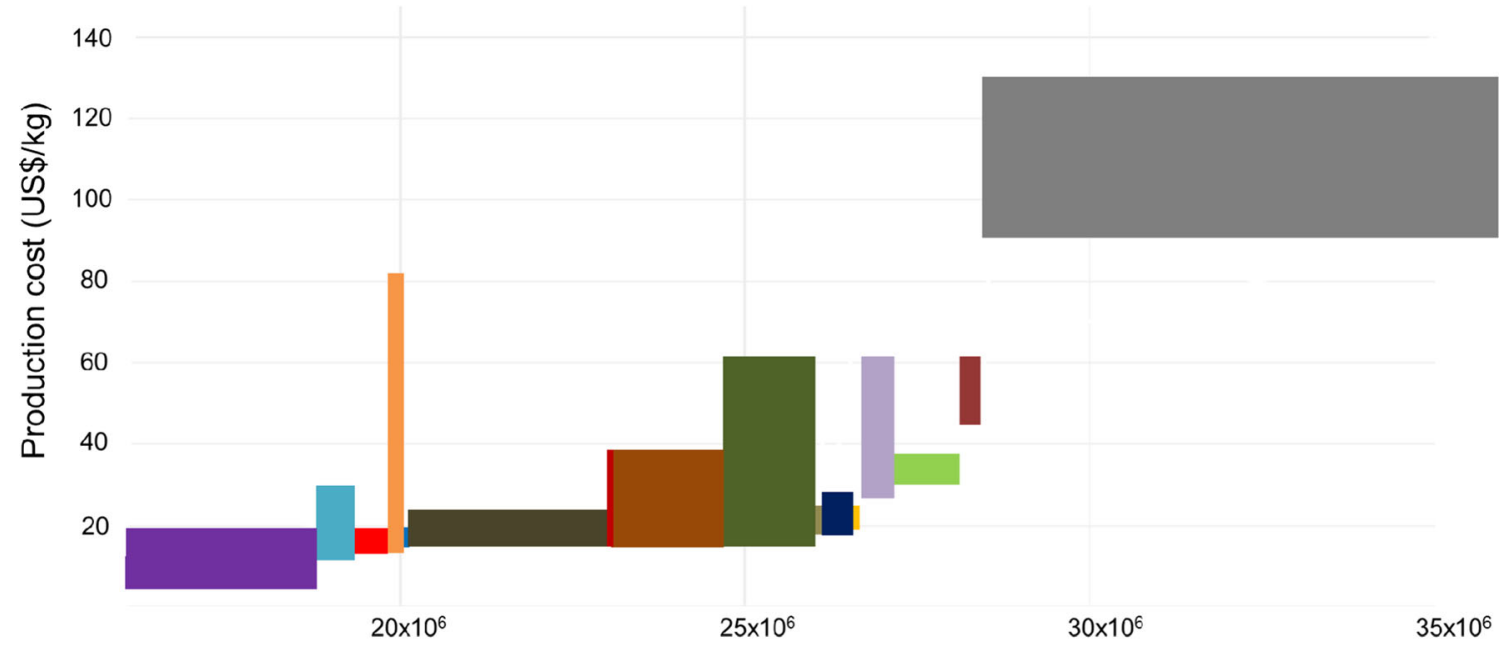

Cumulative availability (tonnes)
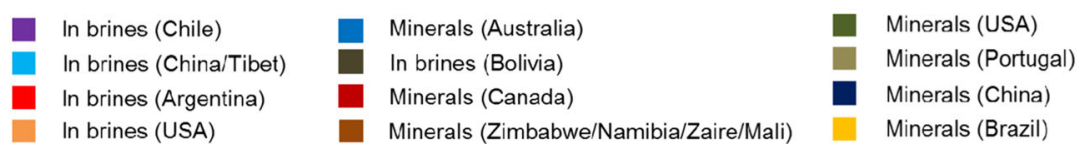

Minerals (Russia) In brines (Israel/Jordan)

Hectorites (USA)

Oceans

Fig. 4 Cost-cumulative availability of lithium per deposit

difference are twofold. First, society places a higher value on PGMs than on lithium and is thus prepared to spend more to extract $1 \mathrm{~kg}$ of, for example, palladium than it is for the same quantity of lithium. Second, the available resources for lithium are incomparably higher than for PGMs.

\subsection{Surplus cost potential for PGMs and lithium}

The cumulative supplies, estimated as in Sun et al. (2011) (mineral demand adjusted to mineral supply from recycling), of primary PGMs and lithium based on scenario analysis (up to 2070) are presented in Fig. 6. These scenarios are somewhat optimistic, especially with regard to the rate at which the automotive sector shifts to full electrification and fuel cells.

As was evident in Fig. 6, supply of primary PGMs by 2070 is greatest in scenario 1 , as in this case, diesel and petrol vehicles will continue to be dominant in the future. In scenarios 2 and 3, supply of PGMs will slacken after
2030 as PHEVs and EVs begin to replace cars with internal combustions engines. EVs do not require the use of PGMs, while PHEVs need significantly smaller quantities than petrol and diesel cars (see Table 1). In scenario 2, this trend will continue up to the point where FCVs become fully commercialised. With an increase in sales of FCVs, supply of PGMs will increase at a higher rate than in scenario 1 as these cars use more PGMs in their catalysts than internal combustion engines. Hence, after 2070, the cumulative supply of PGMs in scenario 2 should exceed the supply in scenario 1 . Scenario 3 assumes that no FCVs will be used in the future due to technological limitations. For this reason, supply of PGMs in the automotive sector will systematically decrease as the world shifts towards full electrification. In fact, after 2070, supply of PGMs in the automotive sector will be lower than for other sectors. Use of PGMs in the automotive sector will continue, albeit at a lower rate, mainly for MDVs and
Table 3 Average MCI calculations in US\$ per kilogramme of mineral produced

\begin{tabular}{lllll}
\hline Metal & $\begin{array}{l}\text { MCI } \\
\left(U S \$_{2014} / \mathrm{kg}\right)\end{array}$ & $\begin{array}{l}\text { Std. dev. } \\
\left(\mathrm{US}_{2014} / \mathrm{kg}\right)\end{array}$ & $\begin{array}{l}95 \% \text { confidence } \\
\text { interval-lower } \\
\text { boundary }\left(U S \$_{2014} / \mathrm{kg}\right)\end{array}$ & $\begin{array}{l}95 \% \text { confidence } \\
\text { interval—upper boundary } \\
\left(\mathrm{US} \$_{2014} / \mathrm{kg}\right)\end{array}$ \\
\hline Platinum & $1.019 \times 10^{-3}$ & $3.852 \times 10^{-5}$ & $9.434 \times 10^{-4}$ & $1.094 \times 10^{-3}$ \\
Palladium & $5.967 \times 10^{-4}$ & $5.889 \times 10^{-6}$ & $5.852 \times 10^{-4}$ & $6.082 \times 10^{-4}$ \\
Rhodium & $1.186 \times 10^{-2}$ & $1.144 \times 10^{-4}$ & $1.164 \times 10^{-2}$ & $1.208 \times 10^{-2}$ \\
Ruthenium & $7.344 \times 10^{-4}$ & $1.002 \times 10^{-6}$ & $7.325 \times 10^{-4}$ & $7.364 \times 10^{-4}$ \\
Iridium & $2.292 \times 10^{-2}$ & $6.344 \times 10^{-5}$ & $2.280 \times 10^{-2}$ & $2.305 \times 10^{-2}$ \\
Lithium & $1.116 \times 10^{-9}$ & $4.815 \times 10^{-11}$ & $1.022 \times 10^{-9}$ & $1.210 \times 10^{-9}$ \\
\hline
\end{tabular}



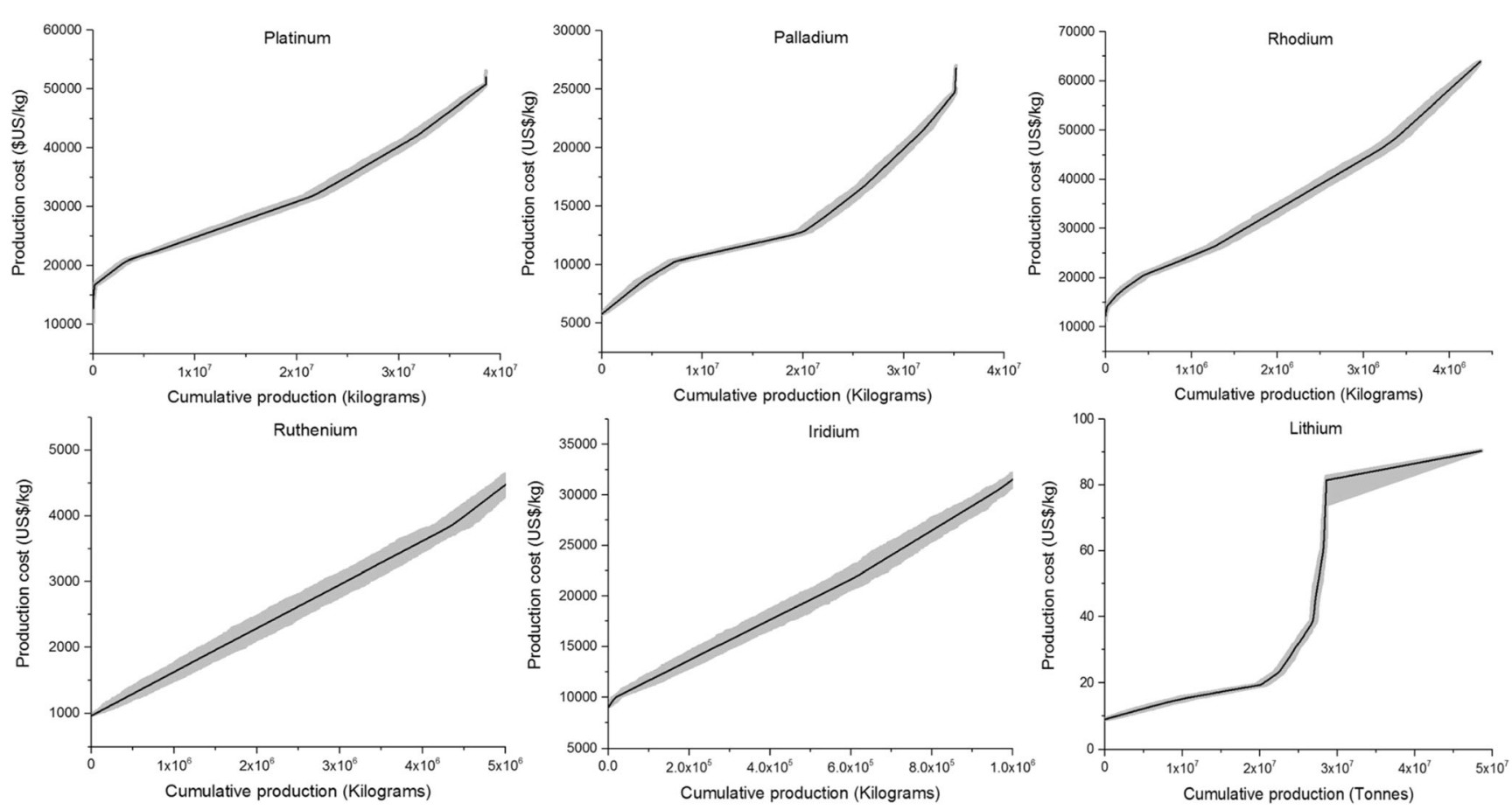

Fig. 5 Cost-cumulative production curves (mean slope) for each mineral derived based on Monte Carlo simulations with the grey area representing the cost range

HDVs, which will themselves progress towards electrification at a much slower pace than LDVs.

The cumulative supply scenarios for primary lithium are expected to work conversely to those for PGMs. In scenario 1, supply of lithium for other sectors will grow at a faster rate than supply for the automotive sector as no electrification of vehicles is assumed. In scenario 2, supply of lithium will grow substantially by 2050 before weakening in line with increasing sales of FCVs. The rate of growth in the supply of lithium will be at its greatest in scenario 3 , once the road transport industry shifts to PHEVs and EVs.

Based on these future primary mineral supply scenarios and by applying the decreasing discounting rate, surplus cost estimates were calculated for PGMs and lithium, as presented in Table 4. These estimates were supplemented with the current average production costs for PGMs and lithium for comparison.

The supply levels for platinum, palladium, rhodium, ruthenium and iridium, as part of total supply of PGMs,
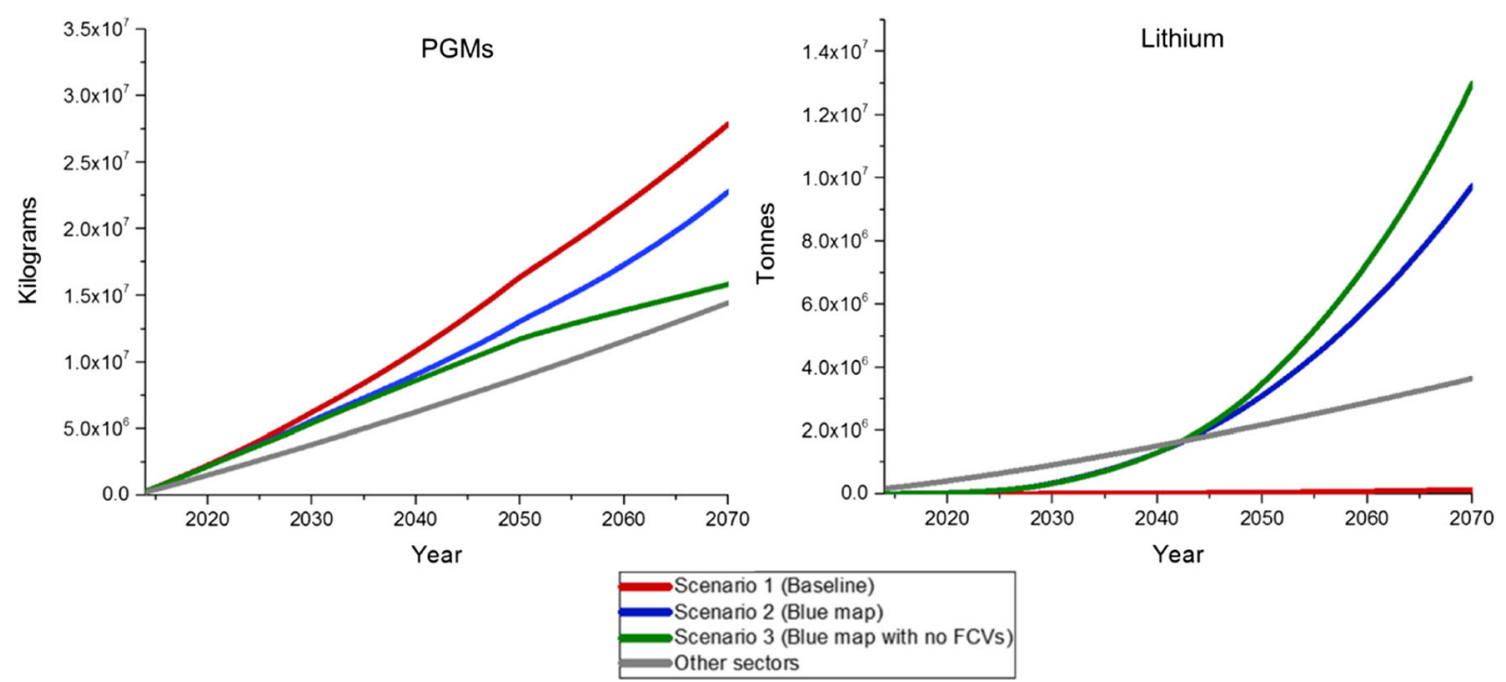

Fig. 6 Cumulative supply of primary PGMs and lithium in the automotive sector based on three different scenarios, and in other sectors 
were established based on historical data published by Johnson Matthey (2013a) (platinum, 46\%; palladium, 43\%; rhodium, $5 \%$; ruthenium, $5 \%$; iridium, $1 \%$ ). These proportions can, of course, change, as only platinum, palladium and rhodium are currently used in autocatalysts and supply of these metals will grow at higher rate than of iridium and ruthenium. However, this assumption was made based on the fact that most PGMs are mined together and production of platinum and palladium currently determines maximum production of the others. Furthermore, ruthenium also has the potential to be used in catalysts, particularly in fuel cells (Albers et al. 2008).

Regardless of the scenarios considered, PGMs have hundreds to thousands times higher surplus cost values than lithium. However, once compared with the current production costs, the differences between PGMs and lithium are not that significant and they vary depending on the scenario considered. For example, surplus costs for ruthenium are about 37 (scenario 1), 33 (scenario 2) and $29 \%$ (scenario 3) of the current production costs. These proportions for lithium work conversely to those for ruthenium and are as follow: 10 (scenario 1), 28 (scenario 2) and 34\% (scenario 3) of the current production costs. These results indicate that problematic price increases of lithium are unlikely if the latest technological trends in the automotive sector will continue up to 2070. Surplus costs for ruthenium are approximately one-third of the current production costs in all scenarios; hence, a threat of their price increases by 2070 will largely depend on the discovery of new deposits and the ability of new technologies to push these costs down over time. This also applies to lithium if the increasing electrification of road transport will continue up to 2070 .

\section{Discussion}

Evaluation of environmental impacts in the context of LCIA is always a choice of both midpoint and endpoint measures (Hauschid et al. 2013; Jasinski et al. 2016). Measures at the midpoint level are indicators placed at the location in the impact pathway and the endpoint modelling measures the severity of the damage that is modelled by the midpoint indicator (Hauschild et al. 2013). Existing estimates of surplus cost for metals are based on midpoint-to-endpoint modelling by linking the ore grade decrease function with the increasing marginal extraction costs of resources (Goedkoop et al. 2008). However, to date, an exact causal relationship between ore grade decrease and surplus costs has not been established (Vieira et al. 2016). Ponsioen et al. (2014), in the LC-Impact project, estimated surplus cost for fossil fuels without midpoint-to-endpoint modelling. They confirmed the suggestions made by Jolliet et al. (2004) that in some cases of modelling, at the endpoint level, the pathway could be better modelled without the inclusion of an indicator at the midpoint level. This study proves that minerals other than fossils (e.g. metals) can be modelled without an ore grade decrease function, something that in any case has been heavily criticised by authoritative bodies (Drielsma et al. 2016).

Existing studies into surplus cost confirmed that the major difficulty in estimating a surplus cost indicator relates to the acquisition of data for the production cost of minerals. These costs were either assumed constant across all mines (Goedkoop et al. 2008), or provided by authoritative institutions, such as the IEA (Ponsioen et al. 2014), or purchased from commercial databases (Vieira et al. 2016). This study showed that it is possible to collect own data and create original cost-cumulative availability curves in order to calculate a surplus cost indicator. The construction of these curves is both time and resource intensive as it requires browsing data from a number of different sources. For example, a master's student spent approximately 1 year on the collection of data for lithium with the assistance of various industry and government officials, historical documents and studies (Yaksic and Tilton, 2009). The data collection process for PGMs was less intense and it took approximately 3 months, between
Table 4 Surplus cost potential for each mineral in three different production scenarios compared with the current average production costs

\begin{tabular}{lcccc}
\hline & \multicolumn{2}{l}{ Surplus cost US\$2014 $/ \mathrm{kg}$} & $\begin{array}{l}\text { Current average production } \\
\text { costs US } \$_{2014} / \mathrm{kg}\end{array}$ \\
\cline { 2 - 4 } Metal & $\begin{array}{l}\text { Scenario 1 } \\
\text { (baseline) }\end{array}$ & $\begin{array}{l}\text { Scenario 2 } \\
\text { (Blue map) }\end{array}$ & $\begin{array}{l}\text { Scenario 3 (Blue map } \\
\text { with no FCs) }\end{array}$ & \\
\hline Platinum & 8354 & 7428 & 6545 & 37,859 \\
Palladium & 4573 & 4066 & 3583 & 19,665 \\
Rhodium & 10,569 & 9398 & 8281 & 31,934 \\
Ruthenium & 655 & 583 & 513 & 1767 \\
Iridium & 4086 & 3633 & 3201 & 15,129 \\
Lithium & 1.7 & 4.9 & 5.8 & 17.3 \\
\hline
\end{tabular}


January and March 2016. The quality of data collected is comparable to data from expert-driven consulting services. For instance, the average surplus cost values derived from the LC-Impact (Vieira et al. 2016) and this study represent a good fit with factor differences of $1.04,1.85$ and 0.62 for platinum, palladium and rhodium, respectively. The LC-Impact is based on real mining cost data purchased from the commercial database World Mine Cost Data Exchange. It would be both unexpected and surprising if the data were to match perfectly as the two methods are based on slightly different assumptions and have different data coverage.

Cost-cumulative availability curves, on which a surplus cost indicator is based, constructed for PGMs and lithium reflect the availability of minerals only from known deposits under current conditions (this is, current technology, prevailing labour and other input prices, and so on). Ideally, these curves should concern all known and unknown deposits as well as their current and future production costs (Yaksic and Tilton 2009). This, however, is rarely the case in practice as reliable information on unknown deposits and future technological developments is not available. A single attempt to construct this curve based on both known and unknown deposits can be found in Aguilera et al. (2009). According to Yaksic and Tilton (2009), this does not pose a serious problem as long as one keeps in mind that both new discoveries and the cost-reducing effect of new technology are likely to shift these curves down and to the right over time. It needs to be recognised that cost-cumulative curves are not fixed, and they have tendency to move around with each periodic update of the curve (Humphreys 2013; Drielsma et al. 2016). Hence, it is likely that new blocks will be continuously added to cost-cumulative availability curves for PGMs and lithium between now and 2070 as geological knowledge and extraction technology improves. This, in turn, will have an impact on surplus cost estimates for these metals, which currently do not incorporate any information about technological change over time and entry of new high-quality mines to the market. It is expected that new discoveries and technologies will shift surplus costs down in the future. Hence, the results provided in this paper can be interpreted as the upper cost limits (the worst-case possibilities), which are likely to be decreasing with the discovery of new deposits and cost-reducing technologies. The surplus cost estimates can be easily updated if new data become available in the future.

Considering the fact that cost-cumulative availability curves for PGMs and lithium (and resultant surplus cost estimates for these metals) capture only a small part of the total available resources and utilise the current production costs data, the results should not be interpreted as an indication of availability and potential scarcity of these resources in the long-run. Tilton and Lagos (2007) and Humphreys (2013) explained that the long-run mineral costs and prices are far more reliable warning indicators of future resource scarcity or lack of availability. This, however, is both a limitation and a strength of this work. Modelling these costs and prices in the long-run may suffer from huge uncertainties and significant inconsistencies by trying to anticipate something that nobody can know much (Humphreys, 2013). These uncertainties were avoided in this study by providing a mid-term outlook for the real threat of PGMs and lithium scarcity and the potential economic implications of their depletion from now up to 2070. Drielsma et al. (2016) recommended that existing cost-cumulative availability curves are the most suitable to analyse individual minerals in the 30-100-year time frame.

\section{Conclusions}

This study has developed the life cycle impact assessment characterisation factors for platinum group metals and lithium to 2070 based on the surplus cost indicator. The surplus cost was calculated for three different scenario projections for future mineral production considering future market dynamics, recyclability rates, demand-side innovation and technological developments (particularly in the automotive sector) and economic growth. Surplus cost estimates (in US dollars per kilogramme in the year 2014) ranged from US\$ 6545-8354 for platinum, US\$ 3583-4573 for palladium, US\$ 828110,569 for rhodium, US\$ 513-655 for ruthenium, US\$ $3201-4086$ for iridium and US\$ $1.70-5.80$ for lithium.

This study sheds a useful view on whether depletion of PGMs and lithium could have any serious economic consequences from now up to 2070 under different production scenarios. Compared with the current production costs, the results indicate that problematic price increases of lithium are unlikely if the latest technological trends in the automotive sector will continue up to 2070. Surplus costs for PGMs are approximately one-third of the current production costs in all scenarios; hence, a threat of their price increases by 2070 will largely depend on the discovery of new deposits and the ability of new technologies to push these costs down over time. This also applies to lithium if the increasing electrification of road transport will continue up to 2070.

Surplus cost estimates for PGMs and lithium are based on cost-cumulative availability curves, which at the moment, capture only a small part of the total available resources (only known deposits) and utilise the current production costs data. Hence, the results of this study should be interpreted in the short- to mid-term (from now up to 2070) and not as an indication of availability and potential scarcity of these resources in the long-run (post 2070). Modelling and incorporating 
unknown deposits and potential future mineral production costs into these curves is the subject of future work. However, one needs to bear in mind that modelling these variables in the long-run may suffer from huge uncertainties and significant inconsistencies by trying to anticipate something that nobody can know much.

Regardless of these limitations, this study provides useful insight into the availability of PGMs and lithium up to 2070. It provides information about geological and economic risks of minerals depletion in the short-term and thus help to address these risks in the most optimal manner. It also proves that if time and resources permit, reliable surplus cost estimates can be calculated, at least in the short-run, based on the construction of one's own curves with the level of quality comparable to expert-driven consulting services. The results are not fixed and should be periodically updated if new data become available between now and 2070.

Acknowledgements We wish to thank the subject editor Mrs. Andrea Russell-Vaccari and the reviewers for extremely valuable comments on this paper. We are also grateful to the Engineering and Physical Sciences Research Council and Jaguar Land Rover for funding this research (EP/ I01585X/1). All data are provided in full in the results section of this paper and supplementary information.

Open Access This article is distributed under the terms of the Creative Commons Attribution 4.0 International License (http:// creativecommons.org/licenses/by/4.0/), which permits unrestricted use, distribution, and reproduction in any medium, provided you give appropriate credit to the original author(s) and the source, provide a link to the Creative Commons license, and indicate if changes were made.

\section{References}

Aguilera RF, Eggert RG, Lagos CG, Tilton JE (2009) Depletion and the future availability of petroleum resources. Energy J 30:141-174

Albers PW, Weber W, Kunzmann K, Lopez M, Parker SF (2008) Characterisation of carbon supported platinum-ruthenium fuel cell catalysts of different degree of alloying. Surf Sci 602:3611-3616

Barreto H, Howland F (2005) Introductory econometrics: using Monte Carlo simulation with Microsoft excel. Press, Cambridge University

British Geological Survey (BGS) (2009) Platinum. Natural Environment Research Council, London

Bloxham L (2009) Final analysis: the impact of CO2 legislation on PGM demand in autocatalysts. Plat Met Rev 53:179-180

Cooper J, Beecham J (2013) A study of platinum group metals in threeway autocatalysts. Plat Met Rev 57:281-288

Cropper ML, Freeman MC, Groom B, Pizer WA (2014) Declining discount rates. The Am Econ Rev 104:538-543

Crundwell FK, Moats M, Ramachandran V, Robinson T, Davenport WG (2011) Extractive metallurgy of nickel, cobalt and platinum group metals. Elsevier

Dewulf J, Bösch ME, Meester BD, Vorst GVD, Langenhove HV, Hellweg S, Huijbregts MA (2007) Cumulative exergy extraction from the natural environment (CEENE): a comprehensive life cycle impact assessment method for resource accounting. Envir Sci Tech 41:8477-8483
Drielsma JA, Russell-Vaccari AJ, Drnek T, Brady T, Weihed P, Mistry M, Simbor LP (2016) Mineral resources in life cycle impact assessment - defining the path forward. Int J Life Cycle Ass 21:85-105

Drury CM (2013) Management and cost accounting. Springer, Andover

EC-JRC (2011) Recommendations for life cycle impact assessment in the European context. ILCD Handbook-International Reference Life Cycle Data System, European Union

Field A (2009) Discovering statistics using SPSS. Sage Publications

Finnveden G, Östlund P (1997) Exergies of natural resources in life-cycle assessment and other applications. Energy 22:923-931

Goedkoop M, Heijungs R, Huijbregts M (2008) A life cycle impact assessment method which comprises harmonised category indicators at the midpoint and the endpoint level. Report I: characterisation, den Haag, Ministerie van VROM Rijnstraat

Goedkoop M, Spriensma R (2001) The eco-indicator 99: a damage oriented method for life cycle impact assessment: methodology report. Amersfoort, Pré Consultants

Goonan TG (2012) Lithium use in batteries. US Geological Survey

Graedel T, Allwood J, Birat J-P, Buchert M, Hagelüken C, Reck BK, Sibley SF, Sonnemann G (2011) Recycling rates of metals: a status report. United Nations Environment Programme

Guinée JB (1995) Development of a methodology for the environmental life-cycle assessment of products: with a case study on margarines. $\mathrm{PhD}$ Thesis, Leiden University

Hagelüken C, Meskers CE (2010) Complex life cycles of precious and special metals. In book: Linkages of sustainability. MIT Press

Hauschild M, Wenzel H (1998) Environmental assessment of products. Scientific background, vol. 2, UK, Chapman \& Hall

Hauschild MZ, Goedkoop M, Guinée J, Heijungs R, Huijbregts M, Jolliet O, Margni M, De Schryver A, Humbert S, Laurent A (2013) Identifying best existing practice for characterization modeling in life cycle impact assessment. Int J Life Cycle Assess 18:683-697

Treasury HM (2003) The green book-appraisal and evaluation in central government: treasury guidance. TSO, London

Hoatson DM, Miezitis Y, Jaireth S, Huston DL (2014) Platinum-group elements in Australia. Geological setting, mineral systems, and potential. Geoscience Australia-Department of Industry

Huijbregts MA, Hellweg S, Frischknecht R, Hendriks HW, Hungerbühler $\mathrm{K}$, Hendriks AJ (2010) Cumulative energy demand as predictor for the environmental burden of commodity production. Environ Sci Technol 44:2189-2196

Humphreys D (2013) Long-run availability of mineral commodities. Miner Econ 26:1-11

Jarvis M, Lange G-M, Hamilton K, Desai D, FRaumeni B, Edens B, Ferreira S, Li H, Chakraborti L, Kingsmill W (2011) The changing wealth of nations: measuring sustainable development in the new millennium. The World Bank

Jasiński D, Meredith J, Kirwan K (2016) A comprehensive framework for automotive sustainability assessment. J Clean Prod 135:1034-1044

Matthey J (2013a) Market data tables. Johnson Matthey, Royston

Matthey J (2013b) Platinum 2013. Johnson Matthey, Royston

Jolliet O, Margni M, Charles R, Humbert S, Payet J, Rebitzer G, Rosenbaum R (2003) IMPACT 2002+: a new life cycle impact assessment methodology. Int J Life Cycle Assess 8:324-330

Jolliet O, Müller-Wenk R, Bare J, Brent A, Goedkoop M, Heijungs R, Itsubo N, Peña C, Pennington D, Potting J (2004) The LCIA midpoint-damage framework of the UNEP/SETAC life cycle initiative. Int J Life Cycle Assess 9:394-404

Kahn J, Greene P (2013) Selecting discount rates for natural capital accounting. Issue paper, 2. The UK Office for National Statistics

Korn R, Korn E, Kroisandt G (2010) Monte Carlo methods and models in finance and insurance. CRC Press

Levin R, Rubin D (1998) Statistics for Management. Prentice-Hall International, New Jersey 
Lindeijer E, Müller-Wenk R, Steen B (2002) Impact assessment of resources and land use. In book: life cycle impact assessment: striving towards best practice. Florida, SETAC

Lowe M, Tokuoka S, Trigg T, Gereffi G (2010) Lithium-ion batteries for electric vehicles: the US value chain. Governance \& Competitiveness, Duke University, Center on Globalization

Moumakwa D (2014) Operating platinum group metal mines in South Africa, 2014. South Africa-Department of Mineral Resources

Müller-Wenk R (1998) Depletion of abiotic resources weighted on base of "virtual" impacts of lower grade deposits used in future, Institut für Wirtschaft und Ökologie. Universität St, Gallen

Nassar N, Graedel T, Harper E (2015) By-product metals are technologically essential but have problematic supply. Sci Adv 1:e1400180

Nguyen T, Andress D, Troops T, Sujit D (2014) Platinum group metals (PGM) for light-duty vehicles. The United States of AmericaDepartment of Energy

Natural Resources Canada (NRC) (2015) Minerals and metals fact book-2015. Ministry of Natural Resources

Ponsioen TC, Vieira MD, Goedkoop MJ (2014) Surplus cost as a life cycle impact indicator for fossil resource scarcity. Int J Life Cycle Assess 19:872-881

Raychaudhuri S (2008) Introduction to monte carlo simulation. 2008 Winter simulation conference, 7-8 Dec 2008. IEEE, 91-100

Ringland G, Schwartz PP (1998) Scenario planning: managing for the future. John Wiley \& Sons

Rørbech JT, Vadenbo C, Hellweg S, Astrup TF (2014) Impact assessment of abiotic resources in LCA: quantitative comparison of selected characterization models. Envir Sci Technol 48:11072-11081

Saurat M, Ritthoff M (2013) Calculating MIPS 2.0. Resources 2:581-607

Schneider L, Berger M, Schüler-Hainsch E, Knöfel S, Ruhland K, Mosig J, Bach V, Finkbeiner M (2014) The economic resource scarcity potential (ESP) for evaluating resource use based on life cycle assessment. Int J Life Cycle Assess 19:601-610

Steen B (1999) A systematic approach to environmental priority strategies in product development (EPS): version 2000-models and data of the default method. Citeseer
Stewart M, Weidema BP (2005) A consistent framework for assessing the impacts from resource use - a focus on resource functionality. Int J Life Cycle Assess 10:240-247

Sun Y, Delucchi M, Ogden J (2011) The impact of widespread deployment of fuel cell vehicles on platinum demand and price. Int $J$ of Hydrogen Energ 36:11116-11127

Tanaka N (2011) Technology roadmap: electric and plug-in hybrid electric vehicles. International Energy Agency, Tech Rep

Taylor P (2010) Energy Technology Perspectives 2010. Scenarios \& strategies to, 2050. International Energy Agency, Tech Rep

Theart H, De Nooy C (2001) The platinum group minerals in two parts of the massive sulphide body of the Uitkomst Complex, Mpumalanga, South Africa. S Afr J Geol 104:287-300

Tilton JE (2003) On borrowed times? Assessing the threat or mineral depletion. Washington, Resources for the Future

Tilton JE, Lagos G (2007) Assessing the long-run availability of copper. Resour Policy 32:19-23

UN System of Environmental-Economic Accounts (2012) System of environmental-economic accounting central framework. United Nations Publications

US Geological Survey (USGS) (2014) 2014 Minerals YearbookPlatinum-Group Metals. U.S. Geological Survey, Department of the Interior

Van Der Heijden K (2011) Scenarios: the art of strategic conversation. John Wiley \& Sons

Van Oers L, De Koning A, Guinée JB, Huppes G (2002) Abiotic resource depletion in LCA. Road and Hydraulic Engineering Institute. Ministry of Transport and Water, Amsterdam

Vieira M, Ponsioen TC, Goedkoop MJ, Huijbregts MA (2016) Surplus cost potential as a life cycle impact indicator for metal extraction. Resources 5:2

Yaksic A, Tilton JE (2009) Using the cumulative availability curve to assess the threat of mineral depletion: the case of lithium. Resour Policy 34:185-194

Zientek ML, Causey JD, Parks HL, Miller RJ (2014) Platinum-group elements in southern Africa: mineral inventory and an assessment of undiscovered mineral resources: chapter Q in global mineral resource assessment. US Geological Survey 